\title{
The Ethnic Chinese in Indonesia and Malaysia
}

The Challenge of Political Islam

\begin{abstract}
In the late twentieth century, the Chinese communities in Indonesia and Malaysia were politically repressed. But recent events have prompted optimism that the Chinese communities in both countries could move forward and claim their rightful place as equal citizens. But while the Indonesian Chinese community appears to have made some headway, the situation in Malaysia has not improved, and in some ways, it is worse. We argue that institutional frameworks and political Islam are the main threats to political rights for the Chinese communities in both countries and that there are lessons to be learned from these neighboring nations.
\end{abstract}

KEYWORDS: Malaysia, Indonesia, Chinese, citizenship rights, political Islam

\section{INTRODUCTION}

Malaysia and Indonesia have similar historical and cultural backgrounds. Before the arrival of the European colonialists, both regions were under the rule of Islamic sultanates, which were active in managing the archipelago, often cooperating with each other, but sometimes also competing for influence. Their administrations, as well as European colonial influences, shape the current political system and realities. Malaya gained independence from the British in 1957, and when the Federation of Malaysia was formed in 1963, the issue of the Chinese (and Indian) population was at the center of political calculations. Because their numbers were similar to the indigenous Malay population in Malaya, Tunku Abdul Rahman decided that the federation must include the British colonies in Borneo, namely British North Borneo

James Chin is Director of the Asia Institute, University of Tasmania, Hobart, Australia. TAufiQ TANASAldy is Senior Lecturer in Indonesian and Asian Studies and Head of Global Cultures and Languages, University of Tasmania. Email: <James.chin@utas.edu.au>, <Taufiq.Tanasaldy@ utas.edu.au>.

Asian Survey, Vol. 59, Number 6, pp. 959-977. ISSN ooo4-4687, electronic ISSN I533-838X. (C) 2019 by The Regents of the University of California. All rights reserved. Please direct all requests for permission to photocopy or reproduce article content through the University of California Press's Reprints and Permissions web page, https:/www.ucpress.edu/journals/reprints-permissions. DOI: https://doi.org/ I0.1525/AS.2019.59.6.959. 
(Sabah) and Sarawak, where a sizeable indigenous population could be found. Including the Borneo states meant that the Malays and other indigenous peoples would have a clear majority in the new federation. ${ }^{1}$

The formative years of Indonesia after the formal departure of the Dutch in 1949 focused on stabilizing the diverse nation and pursuing nationbuilding. The percentage of Chinese in Indonesia was far smaller than in Malay(si)a, but was nevertheless seen as problematic. Issues with political loyalty, lack of integration, cultural and religious differences from most of the local population, and economic domination were perceived in both countries.

\section{CONSOLIDATION AFTER THE COLONIAL ERA}

The formal departure of the Dutch from Indonesia in 1949 left the new government with the problems associated with the Chinese who lived in the archipelago. The Chinese remained a distinct community, different from the locals in terms of their role in the economy, their maintenance of their foreign culture, and in the perception of the ambiguity in their political loyalties. But to strengthen nation-building, the post-independence government welcomed their participation in all aspects of life. Aside from some discriminatory economic policies and some cultural aspects, the Chinese were relatively free to pursue their interests and express their aspirations. There were antiChinese riots, and some were serious, but the government firmly condemned them and extended support to the victims. ${ }^{2}$

As has been widely documented, after the New Order under Suharto came to power in 1966, Indonesian Chinese participation in the wider social political arena was reduced to almost zero. ${ }^{3}$ It had once been spearheaded by Baperki (Badan Permusjawaratan Kewarganegaraan Indonesia, the Consultative Body of Indonesian Citizenship), but now there were no longer

I. G. Means, "Malaysia: A New Federation in Southeast Asia," Pacific Affairs 36:2 (1963): 138-59.

2. Some of the most serious occurred right after the end of World War II, when many Chinese were caught between the independence fighters and the former colonizers, intent on returning to their former colony. Massive anti-Chinese riots in Bandung and surrounding areas also broke out in 1963. See chs. 3I, 32, and 44 in B. G. Setiono, Tionghoa dalam pusaran politik [Indonesian Chinese in the whirlpool of politics] (Jakarta: Elkasa, 2003).

3. Baperki was the main social-cum-political organization of the Chinese in the Soekarno era. The New Order government banned leftist organizations and arrested individuals affiliated with them, and Baperki, which was considered leftist, was dissolved. 
Chinese government ministers, and the Chinese were almost unrepresented in the legislative councils at both national and regional levels. In later years their political representation improved, but not significantly.

Throughout the New Order's more than 30 years in power, regulations and bureaucratic treatment of the Chinese were overtly discriminatory. Chinese schools, Chinese publications, and the teaching of Mandarin were banned. ${ }^{4}$ Their social and cultural organizations, which had thrived during the Soekarno era, largely disappeared, leaving only burial associations. Confucianism was derecognized as one of the official religions, and public displays of Chinese cultural activities were prohibited. Chinese were encouraged to adopt Indonesian-style names. Their entry into the state universities was severely restricted, and employment in the public service was almost impossible. ${ }^{5}$ To add further insult, the regime officially referred to them as Cina, which many Chinese regarded as derogatory, instead of the more respectful Tionghoa. ${ }^{6}$ Some of those discriminatory practices were enshrined in formal regulations; others were in the form of tacit approvals or the unwritten code of conduct of the civil administration. ${ }^{7}$

As a minority treated as second-class citizens and facing threats of persecution, for the Chinese, voicing their political aspirations was not an option. Given this hostile environment, the Chinese retreated to business and trading activities, though a few found careers in education and research. Younger generations of Chinese grew up in an environment where political aspirations were not encouraged, either by their family or by the government.

Following quite a similar path was Malaysia in the first decade of independence. The Chinese were part of the ruling Malayan Alliance, led by the United Malays National Organisation (UMNO). At first, the Chinese were mostly left alone in the economic arena, and little was done to bring the indigenous Malay majority into the economy. The Malay share of the economy was negligible compared to that held by British companies and the

4. Only two universities were allowed to teach Mandarin Chinese: the University of Indonesia and Darma Persada University, both in Jakarta.

5. L. Suryadinata, Pribumi Indonesian, the Chinese Minority and China: A Study of Perceptions and Policies (Singapore: Marshall Cavendish International, 2005).

6. C. Coppel and L. Suryadinata, "The Use of the Terms 'Tjina'and 'Tionghoa' in Indonesia: An Historical Survey," Papers on Far Eastern History 2 (I970): 97-II8.

7. T. Lindsey, "Reconstituting the Ethnic Chinese in Post-Soeharto Indonesia: Law, Racial Discrimination, and Reform," in L. Suryadinata (ed.), Ethnic Chinese in Contemporary Indonesia (Singapore: ISEAS, 2008): 57-74. 
Chinese. ${ }^{8}$ But everything changed after the riots of May I3, 1969. They led directly to the suspension of the parliament for more than a year, and a new political framework was put in place when the parliament resumed in 197I. A series of laws were passed, without debate, making it illegal to discuss sensitive issues such as the "special position" of the Malays and other indigenous people (officially called Bumiputera, "sons of the soil"), the citizenship rights of non-Malays, the Malay rulers, and the use of Bahasa Melayu as the official language. ${ }^{9}$ The government then set out to restructure the entire Malaysian political system to conform to the ideology of Ketuanan Melayu (Malay Supremacy). The changes were largely in two areas: politics and the economy.

In politics, UMNO created a new coalition called Barisan Nasional (National Front, BN), where it was made clear that UMNO was first among equals - in other words, all the other parties in the coalition (II to I4 of them) were to be subservient to the political wishes of UMNO. All the key positions in government, including prime minister, deputy prime minister, and defense, education, finance and trade, were given to UMNO. The civil service was completely UMNO-ized and Malayized, as the few non-Malays in the civil service were not replaced. A special, Bumiputera-only, tertiary institution, Universiti Teknologi MARA, was established, with a branch campus in every Malaysian state.

In the economic arena, the New Economic Policy (NEP), an affirmative action policy covering every socioeconomic layer of Malaysian society, was put in place. A quota for Bumiputera (usually 30\%) was imposed for every economic activity, and generous scholarships and subsidies were given to the Malay community. Government-linked companies were required to give contracts to Malay businessmen. More than $90 \%$ of all petrol stations run by PETRONAS, the national oil corporation, were operated by Bumiputera. Under the Industrial Coordination Act, large companies were required to have senior Bumiputera executives, and at least $30 \%$ of their employees and $30 \%$ of the company shares had to be Bumiputera.

Although the NEP officially ended in 1990, its racially discriminatory policies remain in place in all aspects of Malaysian life. By then, the NEP

8. James J. Putchucheary, Ownership and Control in the Malayan Economy: A Study of the Structure of Ownership and Control and Its Effects on the Development of Secondary Industries and Economic Growth in Malaya and Singapore (University of Malaya Co-operative Bookshop, 1979).

9. Gordon Means, Malaysian Politics: The Second Generation (Singapore: Oxford University Press, 199I). 
had come to symbolize the racial divide between Malays and non-Malays in Malaysia. ${ }^{10}$ Mahathir Mohammad, who served as Malaysian prime minister for 22 years (198I-2003), further cemented the Ketuanan Melayu ideology by marginalizing all the non-Malay parties in the $\mathrm{BN}$, so much so that the nonMalay BN parties were seen by the non-Malay population as "window dressing." This led to the rise of the Chinese-based opposition party, the Democratic Action Party. ${ }^{11}$

Mahathir was strongly in favor of authoritarian politics, believing that strongman rule was essential to the multiracial and multireligious country. During his rule, crony capitalism flourished, as the state decided which UMNO-linked capitalists would be awarded government licenses and contracts. ${ }^{12}$ Mahathir also took a hard line on Chinese education and culture: he refused to accept qualifications from independent Chinese high schools, and the National Cultural Policy stated explicitly that Chinese culture was not part of Malaysian culture, which was defined as Malay and indigenous cultures with Islamic elements. In sum, by the turn of the twenty-first century, many Chinese Malaysians felt like second-class citizens and saw the NEP and other pro-Malay government policies as institutional racism.

\section{REGIME CHANGE AND THE CHINESE COMMUNITY}

The second of half of the I990s saw Indonesia experiencing serious economic hardship and growing political opposition. President Soeharto, who had ruled with an iron fist for more than 30 years, was forced to step down in May 1998 after failing to tame the growing grass-roots opposition and massive antiChinese riots in many parts of Indonesia. ${ }^{13}$ The fall of the regime opened up political opportunities for the Chinese. Within two months of the resignation of Soeharto, the Chinese established organizations with a socialpolitical agenda. ${ }^{14}$ Among them were at least three political parties concerned

Io. James Chin, "The Malaysian Chinese Dilemma: The Never Ending Policy (NEP)," Chinese Southern Diaspora Studies 3 (2009): 167-82.

II. James Chin, "Malaysian Chinese Politics in the 2Ist Century: Fear, Service and Marginalisation," Asian Journal of Political Science 9:2 (December 200I): 78-94.

I2. Edmund Terence Gomez and K. S. Jomo, Malaysia's Political Economy: Politics, Patronage and Profits (Cambridge University Press, 2000).

13. J. Purdey, Anti-Chinese Violence in Indonesia, 1996-1999 (Singapore University Press, 2006).

I4. S. Giblin, "Civil Society Groups Overcoming Stereotypes? Chinese Indonesian Civil Society Groups in post-Suharto Indonesia," Asian Ethnicity 4:3 (2010): 353-68. 
with the specific interests of the Chinese. ${ }^{15}$ Other mainstream political parties tried to win sympathy and votes from the Chinese, and recruited them. ${ }^{16}$

In the new democratic elections, more Chinese were elected to the national legislative councils. Eight were elected in 1999, and I4 in 2009. No more than three Chinese had been in the national legislative council in the 30 years of the New Order. The trend is also observable in the region, at the provincial and municipal/district levels. In some Chinese regions in West Kalimantan, the number of elected Chinese legislators also increased. In Pontianak the increase was from merely one or two members to six (1999), then eight (2009), while in Singkawang, the number grew from four (2004) to eight (2009). About a dozen Chinese have been elected into top local and regional executive positions-a new phenomenon in Indonesia's contemporary history. ${ }^{17}$ The first was Yansen Akun Effendy, elected district head (bupati) of Sanggau in West Kalimantan in 1998. The successes occurred not only in the regions with significant Chinese populations, but also in some Christian regions, such as North Sulawesi and East Nusa Tenggara. Surprisingly, there were also successes in areas with small Chinese populations such as East Belitung, Malang, and the Sula Islands. ${ }^{18}$ Chinese are once again being appointed government ministers, with a record number under President Jokowi. There are three Chinese ministers in his current cabinet: Ignasius Jonan, Thomas Lembong, and Enggartiasto Lukito. These achievements surpass even those of Soekarno's era.

The government's changing stance is providing further opportunities for the Chinese. The post-1998 government no longer endorses the active assimilation approach. It has reversed the unfavorable cultural policies mentioned above, and has even made the Chinese Lunar New Year, known as Imlek,

I5. One political party, the Unity in Diversity Party (Partai Bhinneka Tunggal Indonesia), managed to take part in the general election in 1999 and was influential in some regions. J. L. Thung, "Chinese-Indonesians in Local Politics: A Review Essay," Kyoto Review of South East Asia II (2009); Giblin, "Civil Society Groups."

I6. Some have assumed important positions in political (mostly nationalist) parties. In the past there were Sindhunata and Christian Wibisono; and in more recent times, Hendrawan Supratikno, Amir Syamsuddin, Rusdi Kirana, Enggartiasto Lukita, and Hary Tanoe Soedibyo.

17. T. Tanasaldy, "A Decade after the Reform: Political Activism of the Chinese of West Kalimantan, Indonesia," Asian Ethnicity 16:4 (2015): 446-79.

I8. Electoral rules, as well as the combination or pairing of the candidates, and not the support of the majority of the population, could have led to the election (or non-election) of Chinese in some regions. Y.-F. Singkawang Hui, "Decentralization and Chinese Indonesian Politics: The Case of Singkawang, West Kalimantan," Perspective (ISEAS-Yusof Ishak Institute), 2017. 
a public holiday. It has removed all discriminatory policies openly targeting the Chinese. Most important, symbolically, is the removal from the constitution of the requirement that Indonesia's presidential and vice-presidential candidates be "native Indonesians." This means that for the first time in the country's post-colonial history, a Chinese born with Indonesian citizenship, which almost all Chinese are, could be elected to those positions. ${ }^{19}$

The Chinese themselves have responded to the changes enthusiastically. Let's examine a few indicators. The numbers of Chinese candidates running for the national legislative council have increased from 50 in 1999 to 150 in 2004,213 in 2009, and about 350 in the 2014 election. And, as mentioned, several managed to win local executive head elections. Chinese social-cultural organizations have mushroomed, starting with those fighting discrimination. Other associations have also appeared, for Chinese school alumni, professions, clans and surnames, and ethnic and sub-ethnic cultural groups. Chinese media, which had been entirely banned during the New Order, have also exploded in the first few years of democratization. Chinese influence in the media has grown, with Chinese owning some national television stations. ${ }^{20}$ In sum, their role has become more visible in all aspects of life, including sports, entertainment, academia, and research, in addition to their already strong share in business and finance. Not that there was no dissatisfaction or opposition regarding these positive developments-negative sentiments persisted, but the state no longer supported or sponsored them.

\section{The Situation in Malaysia}

In contrast to the dramatic change in Indonesia, political change in Malaysia took more than a decade. The starting point was the retirement of strongman Mahathir Mohamad in 2003. From 2003 to 2009, Malaysia was ruled by Abdullah Badawi, followed by Najib Razak from 2009 to 20I8. Regime change occurred on May 9, 20I8, when the UMNO/BN was defeated by Pakatan Harapan (Alliance of Hope, PH), a new opposition alliance. It was historic and ironic, given that the leader of $\mathrm{PH}$ was none other than Mahathir, who had fallen out with UMNO after his retirement.

19. F. H. Winarta, "No More Discrimination against the Chinese," in L. Suryandinata (ed.), Ethnic Chinese in Contemporary Indonesia (Singapore: ISEAS, 2008): 57-74.

20. Hary Tanoe Sudibyo, a businessman and politician, owns RCTI, MNCTV, and Global TV, while Eddy Kusnady Sariaatmaja owns SCTV and Indosiar. 
When Badawi became prime minister in 2003, he started off with a lot of goodwill. He understood that the Malaysian polity was no longer willing to tolerate the authoritarian rule and crony capitalism of the Mahathir era. His reputation as "Mr. Clean" created a groundswell of support from the Chinese community. Badawi's tagline, "Work with me," was especially appealing to the Chinese, coming on the heels of Mahathir's reputation as a hard-line Malay nationalist. There were high hopes in the Chinese community that Badawi would be fairer to the non-Malays and accept pluralism and multiculturalism. The Chinese were especially happy when Badawi openly admitted to Chinese ancestry and that his wife was half-Japanese. This was in contrast to Mahathir, who had never admitted to his Indian ancestry and instead emphasized his Malay nationalism. The Chinese thus supported Badawi and the $\mathrm{BN}$ strongly in the 2004 general election, hoping that the political capital given to Badawi would lead to fewer anti-Chinese policies and diminished rhetoric.

Less than two years after the election, the Chinese community lost all hope in the Badawi administration when Hishamuddin Hussein Onn, the education minister, brandished a keris (a traditional Malay dagger) during his speech at the 2015 annual UMNO party congress and warned the Chinese against challenging Malay hegemony. Hishamuddin, a son of former Prime Minister Hussein Onn, repeated the gesture at the 2007 congress, despite warnings that it was widely seen as anti-Chinese. The Chinese did not see it as political theater. They saw the keris as an explicit threat and warning to the non-Malay community, especially the Chinese community, not to challenge Ketuanan Melayu but to accept their second-class political status.

The Badawi era also brought more aggressive moves by the Islamic authorities. In Malaysia, the constitution (Article 3) says that "Islam is the religion of the Federation; but other religions may be practised in peace and harmony in any part of the Federation" - granting Islam a unique position but stopping short of making it the official religion. There are laws prohibiting nonMuslims from trying to convert Muslims to other faiths, and all ethnic Malays are constitutionally defined as Muslims. Thus, ethnic Malays do not enjoy freedom of religion, and non-Malays who convert find it legally impossible to leave Islam. ${ }^{21}$

21. N. Abdullah, "Legislating Faith in Malaysia," Singapore Journal of Legal Studies 2007(2): 264-89. 
It gets more confusing, as the sultan is head of Islam and Malay customs in the nine states in the Malaysian federation where a sultanate exists. Nevertheless, the federal Islamic bureaucracy, JAKIM (Malaysia Department of Islamic Development), and its state counterparts regularly interfere in the practice of other faiths. Areas where conversion to Islam has caused political tensions are conversions, custody battles, and funeral rites.

As mentioned, all ethnic Malays are legally defined as Muslims. This means that if a Chinese person marries a Malay, the non-Muslim spouse must convert. In an infamous case in 1988, Azlina Jailani decided to convert to Christianity to marry her boyfriend. Knowing that she could not legally convert out of Islam, she applied to the National Registration Department to change her status by removing the word "Islam" from her identity card. The department told her that only the Syariah Court had the authority to do this. She took her case to court, and almost two decades later, in 2007, the Federal Court, the highest court in Malaysia, ruled that Azlina must appeal to the Syariah Court, which it says is the final authority on Muslim apostasy cases. ${ }^{22}$ There are many cases of Chinese converts who have wished to return to their original religion on divorcing their Malay spouse but are prevented by the Syariah Court and JAKIM.

Custody following broken marriages is another contentious area. In the past decade, there have been many cases where the husband (or wife) converts to Islam secretly in the early stages or in the midst of the divorce. This is usually followed immediately by conversion of under-age children and an order of custody from the Syariah Court. The new convert will refuse to appear before the civil courts in the divorce proceedings, arguing that he or she is now subject to the Syariah Court. The non-converting spouse cannot appear before the Syariah Court, because the Syariah Court is explicitly for Muslims only, thus creating a legal lacuna: the non-Muslim spouse has no legal avenue to contest the custody award. There are hundreds of such cases in Malaysia, where conversion and the Syariah Court are used as a legal strategy to gain child custody. Despite widespread concern in the non-Malay community, the government refuses to promulgate a new law or amendment to resolve this issue. The solution is simple: if the couple were married under civil law, the

22. Even before the Federal Court ruled, Azalina left Malaysia and settled in Australia. In fact, many Malays who have converted to other religions simply leave Malaysia rather than face the legal hurdles, which they feel cannot help them anyway, since the Syariah Court is an Islamic court meant to protect Islam. 
divorce must be heard in the civil courts. There is clear evidence that UMNO is reluctant to bring changes to the law, fearing that it will be accused of siding with the non-Muslims, or even worse, being anti-Islam.

Another issue that creates widespread political tension is funeral rites. There are numerous cases (mostly in the Indian community) where a person enters Islam without telling the family. In many such cases, the new convert practices the old faith: the conversion was a "paper conversion." ${ }^{23}$ It becomes political when the convert dies. This is the moment when the Islamic authorities, JAKIM or its state-level counterparts, show up to take the body away for an Islamic burial. This is often the moment where family members first learn of the deceased's conversion, and some may not accept it, leading to confrontation, at which point the police often support the Islamic authorities, reinforcing the perception that the state is willing to use force to side with Islam.

The political tensions caused by conversion to Islam caused such an uproar in the non-Malay community that in January 2006, nine non-Muslim federal ministers submitted a joint memorandum to Prime Minister Badawi. They asked the federal government (of which they were cabinet members) to review the parallel legal system (civil versus syariah) and issues relating to child custody after the conversions of minors. Within a few days, the nine minsters were forced to publicly withdraw their memorandum. The message could not be clearer: even at the highest level of government, non-Muslims cannot discuss any issue relating to Islam, even if it interferes with the nonMuslim community.

All these issues, coupled with Badawi's reluctance to confront the hard-line Islamists, contributed to BN's poor showing in the 2008 general elections. The BN lost its two-thirds majority in parliament, and Badawi was forced to resign a year later. He was replaced by Najib Razak.

The Chinese community had no great hopes for Najib, as they had had for Badawi. Part of the problem was Najib's anti-Chinese reputation; in 1987 Najib, then leader of the UMNO youth section, had held a political rally where he allegedly said he was willing for a keris to be "soaked in Chinese blood." But far more serious were the corruption allegations against Najib in the IMDB affair. Najib was alleged to be a direct beneficiary of a scam

23. There are many reasons for paper conversions. There are credible reports that people convert to get government aid, a government job, or a promotion in the civil service, or are paid to convert. In almost all of these cases, the individual does not practice Islam; that is, they continue to eat pork, drink alcohol, and take part in non-Muslim religious rituals. 
involving IMDB, a sovereign wealth company established by the Malaysian government. Although the Malaysian Chinese community had always known that corruption existed in the government, they were shocked in this instance because the money, estimated to be close to two billion dollars, was deposited directly into Najib's personal bank account. ${ }^{24}$

Najib's rise to power coincided with the rise of right-wing Malay and Islamic groups. The prominent ones were Pertubuhan Pribumi Perkasa Malaysia (Malaysian Indigenous Power Organisation or Perkasa) and Ikatan Muslimin Malaysia (Malaysian Muslim Network or ISMA). Many of these groups claimed to be the "defenders" of the "Malay race" and "Islam." In their worldview, the non-Muslims in Malaysia, especially the Chinese, are insolent in questioning Ketuanan Melayu and Ketuanan Islam (Islamic supremacy)_that is, the place of Islam and Malay "special rights" in Malaysian society. Their views are simple to summarize: the Chinese and other non-Muslims are pendatang (immigrants) that should be grateful for their Malaysian citizenship and never question their second-place status in Malaysian society. Islam is superior to other religions, or is the true religion. The Malays are superior to the Chinese simply because they are the indigenous people of Malaysia. If the Chinese and the non-Malays want to be treated as political equals, they must assimilate by converting to Islam, adopting Malay and Islamic customs and traditions, and forgetting their Chinese roots.

UMNO's links to these right-wing groups are especially unsettling for the Chinese community. Many of the key office holders of these groups are or were UMNO members or retired senior civil servants. Despite occasional denials by UMNO that it is linked to these groups, the top UMNO leaders have never criticized the hate speech of these groups, thus confirming their intimate links. ${ }^{25}$

\section{POLITICAL ISLAM AND RECENT DEVELOPMENTS}

In both Indonesia and Malaysia, the government plays an important role in leading and influencing public perception. The discriminatory policies of the Indonesian government have helped cement the perception that the Chinese

24. Tom Wright and Bradley Hope, Billion Dollar Whale: The Man Who Fooled Wall Street, Hollywood, and the World (Hachette Books, 2018)

25. James Chin, "Malaysia: Najib's Pyrrhic Victory and the Demise of IMalaysia," Southeast Asian Affairs 4I (2014): 175-89. 
are lesser citizens. The mass media and many social organizations, unfortunately, have been accomplices in this. ${ }^{26}$

The post-New Order government has taken a different approach. Not only has it revoked those discriminatory policies, it has also been supportive of Chinese maintaining their cultural identity and participating actively in all aspect of life, including politics. The state no longer treats Chinese cultural and social activities with suspicion. The media no longer avoid being Chinese-friendly. For example, MetroTV, a news channel owned by a native nationalist, Surya Paloh, has many Chinese reporters and news anchors. Active and more assertive Chinese participation in all aspects of social, cultural, and political life-the result of a supportive government-is an undeniable reality.

Given the support of the government and the global trend toward multiculturalism, public perceptions of the Chinese would be expected to improve. Undeniably, some people continue to hold anti-Chinese views. Most Pribumi (indigenous Indonesians) associated with Islamic organizations which preach a "purer" Islam see the increased presence of the Chinese on the public stage as a threat. ${ }^{27}$ Their interests are intertwined with those of Islamic radicals. They often mobilize to oppose Chinese having an active political role, for example during executive head elections; or disrupt Chinese cultural activities, for example during public celebrations of the lion/dragon dance. That the religion of the Chinese differs from most of the native population has become the key mobilization issue on many recent political occasions.

To illustrate these challenges as well as to envisage the future of the seemingly positive trend toward Chinese participation in politics, we must reflect on what happened with Basuki Tjahaja Purnama, popularly known as Ahok, the controversial Chinese former governor of Jakarta until 20I7. The reason is that, as the governor of the nation's capital, his activities always

26. All printed media, except Indonesia Raya, followed the official prescription to use the term Cina in their reportage (Setiono, Tionghoa dalam pusaran politik). They often exposed the Chinese names of business persons who were found guilty of economic crimes, such as bribery or corruption, despite those individuals being known by their Indonesian names. This entrenched the view that the Chinese, as a race, were associated with those practices.

27. This term is similar to Bumiputera in Malaysia. Unlike their counterparts in Indonesia, the Bumiputera in Malaysia enjoy special rights that have been entrenched in all walks of life, including politics, business, religion, and education. This state-sponsored discrimination has become the main source of grievances of the other main ethnic groups, especially the Malaysian Chinese. 
occurred in the spotlight for the people of the whole nation. His role as the governor of Jakarta was seen by many as very successful, as reflected in his high popularity.

Ahok's political journey is a reflection of the growing role of the Chinese in Indonesian politics. In 2005 he was elected bupati (district head) of Belitung Timur, a district where $86 \%$ of the population professes to be Muslim. He won this election despite his being Christian and Chinese, traits which were used against him by the other candidates in their campaigns. In Jakarta's gubernatorial election in 20I2, Ahok was elected vice governor, accompanying Jokowi, the governor. When Jokowi was elected president in 20I4, Ahok automatically assumed the governorship. In March 2016 he declared his intention to run in the 2017 gubernatorial election as an independent candidate, and received great support from the people of Jakarta. ${ }^{28}$

As governor, Ahok introduced initiatives in education and health care, as well as in other social services that benefit the public, especially the poor. He was successful in improving transportation, cleaning the waterways, and creating green spaces. His policies, including those targeting corruption and poor work ethics in the civil service, were applauded by many. However, his uncompromising attitude made him a number of political enemies, ranging from disgruntled bureaucrats to unhappy members of parliament, who sought his downfall.

He also made enemies on the religious front. In his administration, the activities of radical groups such as those spearheaded by the Islamic Defenders' Front (Front Pembela Islam) were restricted. And some of Ahok's policies were perceived as unfriendly to Islam. ${ }^{29}$ Yet, his support in the Muslim community and the wider population remained very strong, and it seemed that nothing could prevent his being re-elected.

At the end of September 20I6, Ahok mentioned a particular Quranic verse in an official speech, a blunder seized upon by his opponents. A relentless smear campaign managed to turn Muslims away from him. ${ }^{30}$ His approval

28. There are many books about his political journey; see e.g. M. Shoreamanis, Ahok: Politik Akal Sehat (Jakarta: Gramedia, 20I6).

29. An anti-Ahok group posted a comprehensive list of Ahok's sins against Islam: VOA-Islam, "I6 Alasan Umat Islam Menolak Ahok Jadi Gubernur DKI Jakarta," September 26, 20I4, <http:// www.voa-islam.com/read/liberalism/20I4/o9/26/33036/r6-alasan-umat-islam-menolak-ahok-jadigubernur-dki-jakarta/>.

30. He was accused of sins ranging from voting for a non-Muslim governor to denying his supporters their last religious rites: “Deceased Ahok Voter Denied Last Rites," Jakarta Post, March 
rating plummeted, and he was defeated in the election, winning only $42 \%$ of votes. After accelerated court proceedings for blasphemy charges, he was sentenced to two years in jail, and released in January 2019. ${ }^{31}$

There was no doubt from the beginning that although some opposed Ahok, the eventual and bigger target was Jokowi, the current president, his close colleague. Understanding this, Ahok decided not to appeal the sentence. $^{32}$ A few months later, a network of individuals and groups who had mobilized to unseat him through online fake news was uncovered, and some members were jailed. ${ }^{33}$ Several other figures linked with the movements also had run-ins with the law, tarnishing the movements they were leading. ${ }^{34}$ And the organization established after the anti-Ahok movement to solidify political force soon fell apart due to conflicting political aspirations among its core members.

As is clear from this case, public perception of the role of Chinese in Indonesian politics has shifted. Ahok was the antithesis of the stereotypes used against the Chinese, and showed that the Chinese can indeed be loyal and committed citizens, and are not less capable in governance, if they are given a chance. Considering the significant number of votes he received in the election, it is clear that a large segment of moderate Muslims were quite comfortable with Ahok's being a Chinese and Christian governor. This shows greater acceptance. On the other hand, the view that the Chinese, who

II, 20I7, <http://www.thejakartapost.com/news/20I7/o3/II/deceased-ahok-voter-denied-last-rites. html>.

3I. Jewel Topsfield and Karuni Rompies, "Jakarta's Christian Governor Ahok Jailed for Two Years for Blasphemy," Sydney Morning Herald, May Io, 20I7, <http://www.smh.com.au/ world/jakartas-christian-governor-ahok-jailed-for-two-years-for-blasphemy-20170509-gwot4y. html>.

32. Ahok did eventually appeal the charges, after several months in jail. Nivell Rayda, "Former Jakarta Chief Ahok Appeals to Clear His Name of Blasphemy," The Australian, February 20, 20I8, <https://www.theaustralian.com.au/news/world/former-jakarta-chief-ahok-appeals-to-clear-hisname-of-blasphemy/news-story/aadic20ar87c8I2b3oa8bfd89ef4b379>.

33. Members of Saracen were arrested in September 2017: Francis Chan, "Indonesian Police Uncover 'Fake News Factory'," Straits Times, September 17, 20I7, <http://www.straitstimes.com/ asia/se-asia/indonesian-police-uncover-fake-news-factory>. Members of Muslim Cyber Armies were arrested in February 20I8: Chitra Paramaesti, "Police: Characteristics of the Family MCA Similar to Saracen," Tempo.co, February 28, 20I8, <https://en.tempo.co/read/news/2018/02/28/0559I6I3I/ Police-Characteristics-of-The-Family-MCA-Similar-to-Saracen $>$.

34. The cleric Habib Riziek, head of the Front Pembela Islam, has been on the run and refused to return to Indonesia, fearing a jail term due to alleged pornography chats. Several important figures, such as Alfian Tanjung, Buni Yani, Jonru, Patrialis Akbar, and Zumi Zola, have been jailed. 
already have a significant influence on the country's economy, should not be allowed to have a say, or any control, in politics, is not going away anytime soon. Such people are going to continue to voice their opposition.

The defeat of Ahok dented the confidence of the Chinese, as well as those who have been working toward better political parity for the Chinese. Fortunately, the future for the Chinese in Indonesian politics depends more on the reformed political structures that support anti-discrimination legislation and practices. The political role of the Chinese should be measured by their involvement in the stages of the political process, and not merely by election results, let alone a single result.

The prospects for the future remain good, although one can observe the rising influence of sectarian sentiment and Islamic radicalism. While religious street protests have been frequent lately, in reality, most Indonesians have never wanted an Islamic state. In a May 2017 survey by Lembaga Survey Indonesia, only $8.7 \%$ of Indonesians expressed desire for an Islamic state similar to those in the Middle East. ${ }^{35}$ The chance of Islamic parties taking power is slim. The ruling parties have been always dominated by nationalists, and Islamic parties have never occupied the majority of national parliament seats. ${ }^{36}$ Of the 15 political parties running in the 2019 national legislative election, ${ }^{37}$ only three were pure Islamic parties. Their combined performance in the 2019 election was $13.5 \%$, slightly down from 2014 's $15 \% .^{38}$

35. Anisyah Al Faqir, "LSI: Publik ingin demokrasi Pancasila jadi sistem negara dan perekat," Merdeka.com, May 19, 20I7, <https://www.merdeka.com/peristiwa/lsi-publik-ingin-demokrasipancasila-jadi-sistem-negara-dan-perekat.html>.

36. Votes for the all Islamic and Islamist parties (including those with a nationalist platform) have fluctuated, but they have been below $40 \%$ in all post-New Order elections: $37 \%$ in 1999, $38 \%$ in 2004, $29 \%$ in 2009, and 32\% in 20I4. Greg Fealy, "Indonesia's Islamic Parties in Decline," Inside Story, May II, 2009, <http://insidestory.org.au/indonesias-islamic-parties-in-decline>; "Surprise Gains for Islamic Parties in Indonesia Election,” Al Jazeera, April 9, 20I4, <http://america.aljazeera. com/articles/20I4/4/9/indonesia-election.html s.

37. Listed officially were 19 political parties, but four only compete in Aceh Province .

38. They are Partai Bulan Bintang (Moon and Crescent Party, PBB), Partai Persatuan Pembangunan (United Development Party, PPP) and Partai Keadilan Sejahtera (Prosperous Justice Party, PKS). PBB has always been an insignificant player, whereas PPP has suffered infighting and has also been seen as a minor player in post-New Order elections. PKS has lost the confidence of its former supporters due to misconduct by the party's officials, and suffered greatly in past elections. It did better in the 2019 election due to its strong and continuous opposition to the government as well as its efforts toward the demise of Ahok in Jakarta. In the 2019 election they received $0.8 \%, 4.5 \%$, and $8.2 \%$, respectively, compared to $1.5 \%, 6.5 \%$, and $6.8 \%$ in 2014 . 
Efforts by the Islamists to change the national ideology, Pancasila, into a version that favors Islam, have been unsuccessful. ${ }^{39}$ In the midst of growing radical Islam, more recent times have seen the rise of a moderate voice, mostly represented by Nahdlatul Ulama (literally Awakening of Religious Scholars), the largest traditionalist Sunni organization (and the largest Muslim organization) in the country. Together with the nationalists, the moderate Muslims have managed to pressure the government to take action against the radical organizations. ${ }^{40}$

This fighting back by those who used to be silent is observable in the traditional mainstream media as well as in social media. Thanks to Ahok's case, such efforts have spilled over to other cases involving Chinese interests. The voice of support from the majority is longer muted. The forced covering of the statue of a Chinese deity in Tuban, East Java, in August 20I7, for example, provoked a polemical debate among the Muslim population. A similar reaction occurred when a Chinese person challenged a discriminatory land-ownership practice in Yogyakarta in early 20I8. Thus, Ahok's case may turn out to be a blessing in disguise for the Chinese, as the nationalists and moderate Muslims in Indonesia have opened their arms to welcome them into their grand coalition—a gesture never been seen before.

\section{Malaysia}

In Malaysia, the rise of political Islam in the past decade was fueled by three powerful groups: UMNO and the Islamic bureaucracy (JAKIM and its statelevel counterparts); right-wing groups such as Perkasa and ISMA; and PAS (Partai Islam Se-Malaysia, Islamic Party of Malaysia). These groups mostly work independently, but they have links with both UMNO and PAS, and a common objective: the establishment of a Malay-Islamic theocratic state, where the ideologies of Ketuanan Melayu Islam (Malay Islam Supremacy)

39. Pancasila is a set of five guiding principles and the state ideology of Indonesia. Islamists have tried on several occasions to append "with obligation to carry out shari'a for adherents of Islam" (these words are known as piagam Jakarta) to the first principle, "belief in one God," but have failed. On this and the influence of political Islam in Indonesia, see Robin Bush, "Islam and Constitutionalism in Indonesia," in D. K. Linnan (ed.), Legitimacy, Legal Development and Change: Law and Modernization Reconsidered (London: Taylor \& Francis, 2016): 173-92.

40. The government announced in May 2017 that it was taking action to disband Hizb ut-Tahrir, a pro-Islamic State group. Other clerics and members of public who spread religious hatred have also been arrested. 
are embedded in all spheres. Some of these groups are supported by a network of hard-line preachers spreading Wahhabist/Salafist ideology (and financially supported by Saudi Arabia and the Middle East). Their exclusivist version of Islam is gaining ground among the younger Muslim population in Malaysia. ${ }^{41}$

For the Chinese community, the real danger of political Islam is that it precludes any efforts to mount any political opposition. Almost all Islamist groups in Malaysia argue that non-Muslims must not be allowed to take part in any discussion of Islamic issues since they are not part of the faith. Not a single mainstream Islamic organization in Malaysia supports any formal dialogue with non-Muslim groups. For years, the Malaysian Consultative Council of Buddhism, Christianity, Hinduism, Sikhism and Taoism has invited JAKIM and other Islamic authorities to hold an inter-faith dialogue. Each time, these authorities refused to attend in their official capacity, arguing that non-Islamic faiths cannot be put on an equal footing with Islam in Malaysia. They further argue that inter-faith dialogue promotes religious pluralism, which they view as anti-Islam. The deputy prime minister has gone on record calling members of the interfaith panel "small fry," leaving no doubt about how the government views inter-faith issues. ${ }^{42}$ In another infamous incident, in 2007, the government suddenly cancelled an international inter-faith conference dealing with Islam and Christianity. ${ }^{43}$

The defeat of UMNO and regime change in 2018 prompted widespread optimism that things will fundamentally change in Malaysia. The Chinesedominated Democratic Action Party, the second-largest party in the $\mathrm{PH}$ coalition, promotes the ideology of "Malaysian Malaysia," or equal citizenship for all. It is also avowedly secular. The Chinese community was hoping that under $\mathrm{PH}$, the Chinese would be treated more fairly. Their optimism was misplaced. The Islamization of Malay society over the past four decades has totally transformed the political landscape. Political Islam is now the only game in the Malay polity. ${ }^{44}$ The new $\mathrm{PH}$ administration must rely on the

4I. Institute for Policy Analysis of Conflict, "Puritan Political Engagement: The Evolution of Salafism in Malaysia," Report 52, December 2018.

42. "DPM: Interfaith Panel Just 'Small Fry'," Malaysiakini, April I2, 2010.

43. This was the sixth Building Bridges seminar, a series set up in the wake of the September II attacks on the United States. "Dismay at Cancellation of Islam-Christian Meet," Inter-Press-Service, April 30, 2007.

44. Ahmad Fauzi Abdul Hamid, "Shariaization of Malay-Muslim Identity in Contemporary Malaysia," Journal of the Malaysian Branch of the Royal Asiatic Society 91:2 (2018): 49-78. 
Islamic vote as much as the previous UMNO regime to stay in power. The bureaucratization of Islam is another problem. Before the fall of the UMNO regime, $\mathrm{PH}$ spoke of the need to disband JAKIM to promote a more inclusive and moderate version of Islam. But once in power, PH decided to keep JAKIM. Despite JAKIM's exclusivist views of Islam and its promotion of hatred of non-Muslims, $\mathrm{PH}$ deemed disbanding it politically dangerous. Instead, $\mathrm{PH}$ is trying to "reform" JAKIM. ${ }^{45}$

Now in the opposition, UMNO has formed an alliance with PAS, its former political enemy, to promulgate the narrative that Islam and the Malays are under threat. This strategy of using Islam as their main political platform to defeat the $\mathrm{PH}$ at the polls gained traction when the UMNO/ PAS alliance won several by-elections in Malay constituencies, leading to the two parties signing an electoral pact to defeat $\mathrm{PH}$ in the next general election, scheduled for mid-2023. ${ }^{46}$ This leaves no room for the $\mathrm{PH}$ administration to pull back from political Islam. The fear is that if $\mathrm{PH}$ is seen as "less Islamic" than UMNO/PAS, then it will definitely lose.

\section{CONCLUSION}

In Indonesia, institutional and policy changes implemented since 1998 have guaranteed full political rights to the Chinese. Though the effects of years of institutional racism and stereotyping will take time to mend, the prospects for Indonesia are good. Progress has been made, from the appointment of high-ranking officials such as ministers to the growing enthusiasm of Chinese Indonesians to partake in political and social events. Thanks to the constitutional change, a Chinese person can even aim to become president. Although in reality this might not happen soon, in the past it was simply impossible.

In Malaysia, after four decades of institutional racism via the NEP, the capitalistic crony system was unable to accommodate any moves to give political equality to Chinese and non-Malays. Any hopes that UMNO, the ruling party since independence, would open up became politically impossible after the 2008 elections. Once UMNO lost its two-thirds majority in the

45. "Mujahid Pushes for More Inclusive Islamic Reforms," The Star (Malaysia), October 6, 2018.

46. "Fractured Opposition Finding Its Feet," Straits Times, May 5, 2019; James Chin, "New' Malaysia: Four Key Challenges in the Near Term," Lowy Institute Analyses, March I4, 2019, Sydney. 
parliament, it went into survival mode. It essentially discarded ethnicity as its main attraction, preferring to use Islam. Regime change in $2018 \mathrm{did}$ not change the political equation. If anything, it pushed UMNO, now an opposition party, into an even harder line on Islam. It formed an alliance with PAS, the Islamist party, to challenge the new PH government based on the narrative that Islam is "under threat." In this political scenario, the nonMuslim Chinese community became the political bogeyman.

In both Indonesia and Malaysia, the political future of the Chinese has come almost full circle since the fall of Suharto in 1998 and the defeat of UMNO in 2018. The Chinese communities in both countries were cautiously optimistic about their political future, essentially hoping that the new regimes would provide a path to full political and citizenship rights. While the political structure is capable of achieving this with strong political will, the rise of political Islam in both countries means that this positive outlook will face resistance, and in Malaysia could even be halted or reversed. While Islam has always been a political factor in both countries, the blatant use of Islam as the main lever for political support represents a new phenomenon facing the Chinese community.

Political Islam has dominated the main political discourse in a way that sidelines non-Muslims in recent years. It will be an effective way to marginalize the Chinese and non-Muslims, as this is also the political agenda pursued by many people who hold anti-Chinese sentiments. Resisting the rise of political Islam is not an option for the Chinese community, given the sensitive issue of religion in both countries, and their own status as non-Muslims. They do not appear to have any political space to maneuver unless they are supported by friendly political forces.

In Indonesia, the rise of political Islam has been reined in by moderate and pluralist Islamic organizations, including Nahdlatul Ulama. Like the nationalists, they have taken the Chinese under their wing, and thus shielded them from some of the worst effects. In Malaysia, all the major Malay-based political parties and NGOs have adopted the ideology of Ketuanan Malayu Islam, so there is no major group to speak for the non-Muslims and minorities. In summary, looking at cases in the past several years and the rise of political Islam, political trajectories for the Chinese look more positive in Indonesia than in Malaysia. 